
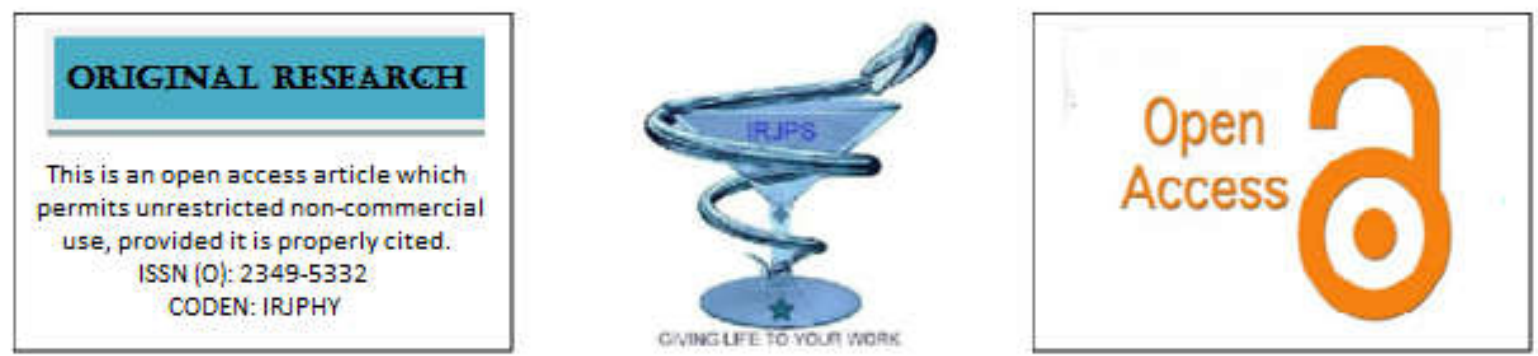

\title{
COMPARISION OF INVITRO ANTIMICROBIAL STUDIES OF CINCHONA AND CEFEXIME ON DRINKING WATER BACTERIA
}

\author{
Mohanraghupathy. S*, Swarnalatha. D, Nagendra. M, Kishore Kumar. D, Rajeev. C, Gouthami. S \\ Dept. of Pharmacology, Annamacharya College of Pharmacy, Andhra Pradesh, India
}

Submitted on: 22.08.19; $\quad$ Revised on: 05.09.19; $\quad$ Accepted on: 07.09.19

\begin{abstract}
The plant Cinchona officinalis belongs to the family Rubiaceae is used as a medicinal plant. Present study has tried to comparative in vitro antimicrobial study (well diffusion method) of aqueous extract of Cinchona and Cefexime drug solution. The antimicrobial study is conducted on drinking water by stagnating initially. Then the water is utilised for the study. The bacteria whatever it is concern in this study we examined whether cinchona or cefexime which is effective. We concluded here cefexime is more effective than cinchona. Cefexime is one of the cephalosporin compound which is very effective towards the gram+ve and gram -ve bacteria.
\end{abstract}

Key Words: Cinchona, antimicrobial study, gram + ve bacteria, gram -ve bacteria,

Corresponding author: Mohanraghupathy.S

E-mail: mohanraghupathy@gmail.com
Indian Research Journal of Pharmacy and Science; 22(2019)1948-1951; Journal Home Page: https://www.irjps.in DOI: $10.21276 /$ irjps.2019.6.3.5 


\section{INTRODUCTION ${ }^{1}$}

Bacteria are microorganisms which are too small to see with the naked eye that exist in virtually all environments in the world. They exist in dirty water, caves, and hot springs, organic materials like fallen trees and dead animals, and inside the bodies of virtually every living animal on earth._Bacteria are of two types they are Gram +ve \& Gram -ve bacteria. Gram+ve bacteria are a class of bacteria that take up the crystal violet stain used in the Gram staining method of bacterial differentiation. The thick peptidoglycan layer in the cell wall that encases their cell membrane retains the stain, making definitive identification possible.

The following are the parts seen in the Gram+ve bacteria. They are: 1.Cytoplasmic lipid membrane 2.Thick peptidoglycan layer 3.Teichoic acids and lipoids are present, forming lipoteichoic acids, which serve as chelating agents, and also for certain types of adherence. Peptidoglycan chains are cross-linked to form rigid cell walls by a bacterial enzyme DD-transpeptidase.

Gram-negative bacteria cannot retain the violet stain after the decolorization step alcohol used in the decolorization process degrades the outer membrane of gram-negative cells making the cell wall more porous and incapable of retaining the crystal violet stain. Their peptidoglycan layer is much thinner and sandwiched between an inner cell membrane and a bacterial outer membrane, causing them to take up the counter-stain (safranin or fuchsine) and appear red or pink. Despite their thicker peptidoglycan layer, gram-positive bacteria are more receptive to antibiotics than gram-negative, due to the latter's relatively impermeable lipid based bacterial outer membrane.

\section{MATERIALS \& METHODS ${ }^{2}$}

Requirements : Petriplates, beakers, conical flasks, Nutrient Agar media, Laminar air flow, Aseptic area, Autoclave, sterile cotton, aluminum foil, borer, micropipette, incubator.

Chemicals required: Ethanol, agar media, drinking water, Cinchona, Cefixime

\section{PROCEDURE}

Step -1 : The first and important step to be followed in invitro studies are maintenance of aseptic area. The apparatus and the equipments are cleaned with hot water and then with ethanol such that the above things become $99 \%$ sterile.

Step - 2: Weigh 250 gms of Nutrient agar by using an electronic balance and dissolve in $500 \mathrm{ml}$ distilled water by boiling. Boil the solution until it gets a clear solution.

Step - 3: Put the agar solution in a conical flask and cover with the sterile cotton and close with aluminum foil such that it is air tight container. Put the agar solution in autoclave and tight the closure of the autoclave. Maintain the standard pressure of $760 \mathrm{~mm}$ $\mathrm{Hg}$ and a temperature of $121^{\circ} \mathrm{C}$ for boiling of water.

Step - 4: After solidification of agar media take the sterile cotton and dip in the drinking water and touch gently on the surface of agar cake present in petriplate and coat the complete plate.

Step - 5: Agar well diffusion method:

After completion of the step -5 the small wells are made with borer such that two bores for Cinchona and two bores for Cefixime. The drug solutions are prepared with different dilutions. The drug solutions are inoculated with the help of micropipettes into the borers. Then incubate the petriplate in incubator for 24 hours. 


\section{RESULTS:}

Table -1 : Comparision of minimum inhibitory concentration and zone of inhibition of Cinchona and Cefexime:

\begin{tabular}{|c|c|c|c|c|}
\hline S. No & Drugs & $\begin{array}{c}\text { Dose } \\
(\boldsymbol{\mu g s})\end{array}$ & $\begin{array}{c}\text { MIC } \\
(\mathbf{m m s})\end{array}$ & $\begin{array}{c}\text { Zone of inhibition } \\
(\mathbf{m m s})\end{array}$ \\
\hline 1 & Cefixime & 10 & 0.5 & 1.5 \\
\hline 2 & Cefixime & 20 & 0.6 & 1.7 \\
\hline 3 & Cefixime & 30 & 0.9 & 1.8 \\
\hline 4 & Cefixime & 40 & 1.2 & 0.1 \\
\hline 5 & Cefixime & 50 & 0.1 & 0.2 \\
\hline 6 & Cinchona & 10 & 0.1 & 0.3 \\
\hline 7 & Cinchona & 20 & 0.2 & 0.3 \\
\hline 8 & Cinchona & 30 & 0.2 & 0.3 \\
\hline 9 & Cinchona & 40 & 0.2 & 1.3 \\
\hline 10 & Cinchona & 50 & & \\
\hline
\end{tabular}

Figure - 1
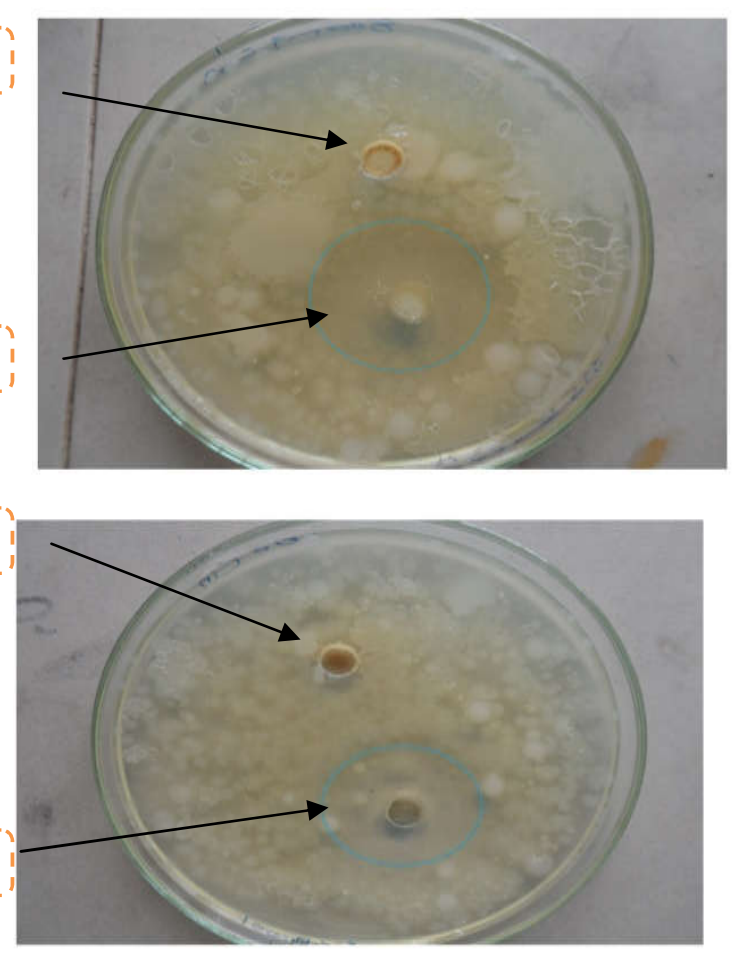

Figure - 3
Figure -2
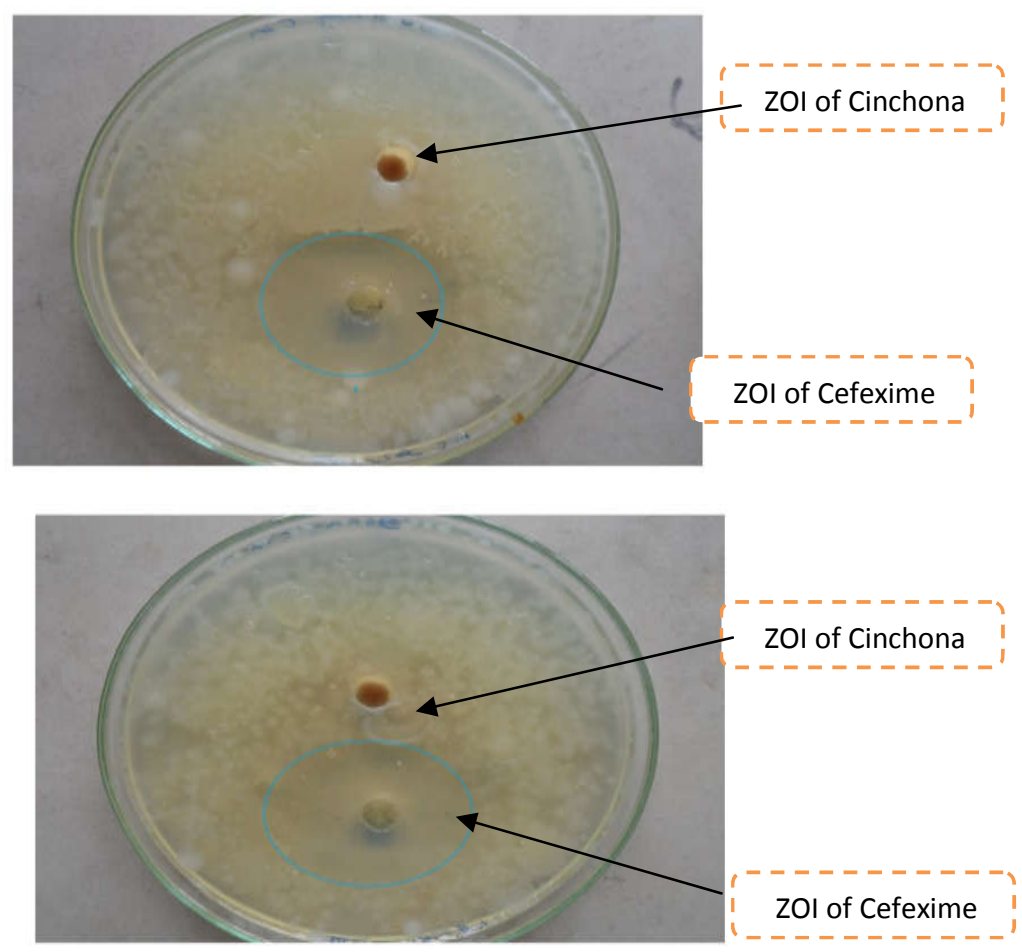

ZOI of Cinchona

Figure -4 


\section{DISCUSSION}

Cinchona is an antimalarial and blood purifier drug. It is also having antipyretic action. Cefexime is a beta lactam antibiotic. It is bactericidal in action. One drug is herbal product and one drug is synthetic. In this research work we want to know whether the Cinchona is having antibacterial activity or not? Hence by comparing with any of the antibiotic this research work has been carried out. In this work the invitro studies have prooved that cinchona is not having any bactericidal or bacteriostatic action. Cefexime is having a good bactericidal action.

\section{CONCLUSION}

In this study finally we prooved that Cefexime is having very good antimicrobial activity when compared to Cinchona. Synthetic drugs are good when compared to herbal drugs but it is upto some limit because we cannot say that no drug is free from the side effect or adverse effect.

\section{REFERENCES}

1. Poxton IR, Arbuthnot JP. Determinants of bacterial virulence, Chap. 13 In: Topley and Wilson's Principles of Bacteriology Virology and Immunity, 8th edn. Vol. 1. London: Edward Arnold 1990.

2. Chandrakant kokare, Agar well diffusion method,p.no27, Hand Book of Bacteriology.V.G.S publications.

3. Relman DA, Falkow S: A molecular perspective of microbial pathogenicity. In: Mandell, Donglas and practice of intertious diseases, 5th ed. Mandell GL, Bennett JE, Dolan R, Churchill Livingstone 2000.

4. Balows A, et a1 1991. Manual of Clinical Microbiology.Washington DC: American Society of Microbiology.

5. Hudson L, Hay FC. Practical Immunology, 3rd edn. Oxford: Blackwell 1989.

6. Stites DP, Terr AI. Basic and Clinical Immunology, 7th edn. Norwalk: Appleton-Lange 1991.

7. K. D. Tripathi, Essentials of medical pharmacology, 625 (1994)

8. Eugene D. \& Weinberg, Burger's Medicinal Chemistry \& Drug Diseases, Fifth Edition, 2, Therapeutic agents, 637 (1997)

9. J. E. Bennet, In Goodman Gilman's the Pharmacological Basis of Therapeutics, Ninth Edition, 1175, (1996)

10. L. D. Gebbharadt, J. G. Bachtold, Proc. Soc. Experimental Biology and Medcine, 88, 103 (1955)

13. D. Greenwood, Antimicrob. Hemotherapy, Third Edition, 62, (1995)

14. Etudes de Rech, Application Science \& Medical Microbiology Abstr., Vol. 9, No. 2, 9A, 1003 (1974). 15. R. H. Khan, S. C. Bahel, Agric Biol. Chem., 40 (9), 1881-1883; Microbiology Abstr., Vol.12, No. 5, 12A, 3701 (1977)

16. A. K. Srivastava, S. C. Bahel, Agriculture Biology \& Chemcals., 40(4), 801-803 (1976); Microbiology Abstr., Vol. 12, No. 4, 12A, 2955 (1977) 